\title{
PERAN GURU BERLATARBELAKANG PENDIDIKAN BERBEDA DALAM PERKEMBANGAN MOTIVASI BELAJAR SISWA
}

\author{
Zuhri Fahruddin \\ STAI Perguruan Tinggi Dakwah Islam Indonesia (PTDII) Jakarta \\ zuhrifahruddin3@gmail.com
}

\begin{abstract}
The learning carried out by the teacher in the classroom must develop the quality of learning, one of which is learning motivation, students who are not passionate about learning are not optimal and of high quality, from this goal the reality is still far from expectations, many students are not aware of the importance of studying seriously, there is no passion study, there is no fun in the study room. The sampling technique used is Census Sample (Sample Saturated), while criterion-based selection is used when conducting qualitative research, 30 students as primary data sources, two teachers as secondary data sources. Data collection techniques using in-depth interviews, observation, documentation and questionnaires, while data analysis by reducing data, presenting data, drawing conclusions and verification by means of research stages I and II students and teachers with a Da'wah educational background, stage III and IV student informants and teachers with PAI educational background.
\end{abstract}

Keyword : Teacher's role, different educational backgrouds, learning motivation

\section{PENDAHULUAN}

Pendidikan merupakan salah aset paling penting bagi suatu negara, tanpa adanya pendidikan negara tidak akan berkembang dari segi peradaban, intelektual, soasial dan budaya. Karena dengan adanya pendidikan nantinya muncul bibit-bibit unggul untuk melanjutkan peradaban sejarah. Maka dari itu negara memfasislitasi pendidikan dengan membuat lembaga pendidikan dibawah naunganKementerian Pendidikan dan Kebudayaan (KEMENDIKBUD) dan Kementerian Agama (KEMENAG) pendidikan formal dan non-formal. Pendidikan non formal meliputi TPQ, Madrasah Diniyah, dan Pesantren, sedangkan pendidikan formal secara bertahap dimulai TK/RA, SD/MI, SMP/MTs, SMA/MA/SMK hingga Perguruan Tinggi. Dari Perguruan Tinggi inilah melahirkan sarjana yang berkompetensi berbeda, karena salah satu tujuan dari Pendidikan Islam adalah agar ada upaya penataan dan modernisasi sistem dan proses pendidikan Islam agar menjadi pendidikan yang bermutu, relevan, dan mampu menjawab perubahan untuk meningkatkan kualitas manusia Indonesia. Berbagai upaya untuk membangun sekolah/madrasah bermutu yang berintegritas tinggi, berkemajuan, berkeunggulan, berdaya 
saing serta mampu menghasilkan lulusan sebagai generasi yang banyak memberi manfaat bagi sesama dimanapun ia berada, telah-sedang dan terus dilakukan. ${ }^{1}$

Kompetensi dari latar belakang pendidikan berbeda dalam menyikapi hidup berbeda, tempat untuk menyalurkan kompetensinya juga berbeda dan memaksa untuk menjalankan kompetensi yang bukan bidangnya menyebabkan hasil tidak maksimal, guru disebuah lembaga pendidikan sangat urgen, tidak dikatakan lembaga pendidikan apabila tidak ada guru atau pengajar, sebab antara mengajar dan mendidik pengertian sangat berbeda, dalam pengertian mudahmendidik sudah tentu mengajar, tapi mengajar belum tentu mendidik, mengajar sifatnya goal oriented, sedangkan mendidik sifatnya value oriented, dan secara teoritis dan praktis juga berbeda.

Kriteria guru dilihat dari relasi di luar dan di dalam kelas dengan siswa berbeda, ada guru hanya bisa mengajar, ada guru hanya bisa mendidik, dan ada guru bisa kedua-duanya (mengajar dan mendidik). Oleh sebab mendidik bukan hanya dilakukan di dalam kelas, maka guru harus bisa melakukan kedua-duanya,Oemar Hamalikberpendapat "Pekerjaan guru merupakan suatu profesi tersendiri, pekerjaan ini tidak dapat dikerjakan oleh sembarang orang tanpa memiliki keahlian sebagai seorang guru”. Banyak yang pandai berbicara tertentu, namun orang itu belum dapat disebut sebagai seorang guru. ${ }^{2}$

Guru yang berlatar belakang non-pendidik hanya bisa mentransfer pengetahuan tanpa memikirkan pahaman siswa, sedangkan kebutuhan siswa bukan hanya satu aspek akan tetapi tiga aspek,aspek pengetahuan (kognitif), aspek sikap (afektif), dan aspek keterampilan (psikomotorik). ${ }^{3}$ Guru di kelas yang orientasinya padaaspek pengetahuan (kognitif) disebut mengajar, walaupun istilah mengajar lebih terkenal di dunia pendidikan dari pada mendidik, Guru harus bisa memadukan ketiga aspek siswa tersebut.

Profesi sebagai guru tidak sama dengan profesi lainnya, banyak kompetensi-kompetensi yang harus dikuasaiguru, diantaranya adalah (1) Kompetensi pedagogik, dalam kompetensi ini guru harus mempunyai kemampuan untuk mengelola pembelajarankelas, merencanakan pembelajaran, dan kemampuan melakukan penilaian, (2) Kompetensi kepribadian, kompetensi ini dilihat dari karakteristik guru dalam kehidupan sehari-hari di lingkungan sekolah atau di

\footnotetext{
${ }^{1}$ Muljawan Asep. (2019).Model dan Strategi Manajemen Lembaga Pendidikan Islam, Jurnal Asy-Syukriyah Vol. 20 Nomor 2 Oktober, h. 54

${ }^{2}$ Oemar Hamalik. 2004.Proses Belajar Mengajar. Jakarta : Bumi Aksara, h. 118.

${ }^{3}$ Zakiah Darajat. (1995).Metodik Khusus Pengajaran Agama Islam.Jakarta: Bumi Aksara, h. 197
} 
luar lingkungan sekolah, guru memberikan tauladan yang baik, dari segi ucapan atau perbuatan, karena pertama yang ditiru oleh siswa adalah perilaku yang tampak, (3) Kompetensi sosial,dalam kompetensi ini guru harus mampu berkomunikasi yang baik dengan semua komponen yang ada dilembaga pendidikan, komunikasi secara humanistik akan lebih membangun keakraban pada komponen lembaga pendidikan, dan (3) Kompetensi profesional, guru dalam kompetensi harus menguasai materi pembelajaran,metode pembelajaran, hingga mampu memberikan motivasi kepada siswa.

Dalam kegiatan pembelajaran motivasi sangat diperlukan, karena motivasi berfungsi untuk memberi stimulus sehingga memunculkan semangat dalam dalam belajar. Menurut Nana Syaodih Sukmadimata, "motivasi mempunyai dua fungsi, yaitu mengarah (directional function) serta mengaktifkan dan meningkatkan kegiatan (activating and energizing function)". ${ }^{4}$

Pembelajaran yang dilakukan Guru di kelas harus mengembangkan kualitas pembelajaran salah satunya dengan motivasi belajar, siswa yang tidak bergairah dalam pembelajaran tidak maksimal dan berkualitas, dari tujuan tersebut realita masih jauh dari harapan, banyak siswa belum sadar pentingnya belajar dengan sungguh-sungguh, tidak ada gairah belajar, tidak ada rasa senang dalam ruangan. Jika dilihat fakta dilapangan, dikarenakan siswa membeda-bedakan dalam proses pembelajaran walaupu sikap membeda-bedakan tidak dengan sengaja dan tanpa sadar dilakukan siswa, akan tetapi dari segi gerak-geriknya siswa dapat terlihat jelas. Oleh sebab itu penliti menganalisis hal ini tujuan secara umum adalah memberitahukan kepada semua Guru agar dalam proses pembelajaran bukan hanya mementingkan perkembangan intelektual, akan tetapi juga spiritual, sosial dan individu yang unggul. Sedangkan tujuan secara khusus agar lebih kreatif dan inovatif dalam pembelajaran hususnya Guru PAI (Pendidikan Agama Islam).

\section{METODE PENELITIAN}

Penelitian ini dilaksanakan pada Tahun 2019 di Madrasah Diniyah Pondok Pesantren Annisfasha Kelapa Gading, Jakarta Utara. Teknik sampling yang digunakan adalah Sampel Sensus (Sampel Jenuh), sedangkan criterion-based selection digunakanpada saat melakukan penelitian kualitatif. ${ }^{5}$ Guru yang berlatarbelakang Dakwah dan Guru PAI sebagai sumber data sekunder, sedangkan 30 siswa sebagai sumber data primer. Sebagai informan dalam penelitian

\footnotetext{
${ }^{4}$ Nana Syaodih Sukmadimata. 2004. Landasan Psikologi Proses Pendidikan. Bandung: PT. Remaja Rosdakarya, h. 62

${ }^{5}$ Creswell, J. W. 2013.Penelitian Kulalitatif \& Desain Riset. Yogjakarta: PT Pustaka Pelajar, h. 94
} 
tahap I dan II siswa dan guru yang berlatarbelakang pendidikan Dakwah, tahap III dan IV informan siswa dan guru yang berlatarbelakang pendidikan PAI. Jumlah informan dan responden penelitian ini guru 2 orang, siswa sebanyak 30 orang, Teknik pengumpulan data menggunakan teknik wawancara mendalam, observasi, dokumentasi dan kuesioner. Analisis data kualitatif menggunakan teknik analisis interaktif, yaitu interaksi dari empat komponen, yaitu reduksi data, sajian data, penarikan kesimpulan serta verifikasi. ${ }^{6}$ Analisis data kuantitatif menggunakan analisis statistik deskriptif, lebih detail dalam keabsahan data, sebagai berikut :

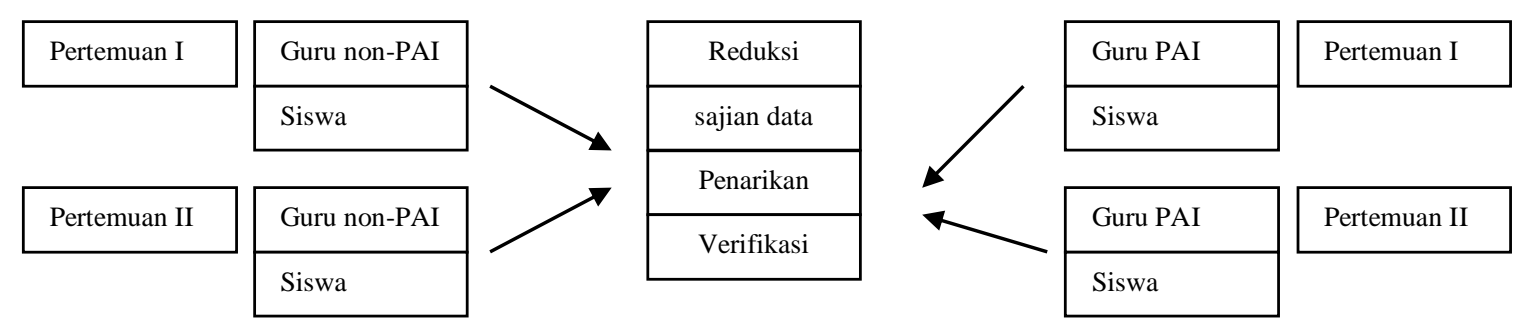

\section{PEMBAHASAN}

\section{Latar Belakang Pendidikan Guru}

Latar belakang pendidikan guru mencerminkan kepribadian, wawasan dan pengalaman guru. Salah salah lembaga pendidikan dikatakan berkualitas apabila latar belakang guruyang dilaksanakan linear, dinamika kepribadian,wawasan dan pengalaman berpengaruh yang ditekuni dalam suatu bidang. Latar belakang pendidikanguru dalam melaksanakan program pembelajaran telah diatur dalam Undang-undang Pemerintah Nomor 19 Tahun 2005 Pasal 28, bahwa "Pendidikan harus memiliki kualifikasi akademik dan kompetensi sebagai agen pembelajaran, sehat jasmani dan rohani serta memiliki kemampuan untuk mewujudkan tujuan pendidikan nasional". Sedangkan Undang-undang Sistem Pendidikan Nasional Nomor 20 Tahun 2003 menjadi guru dilihat dari dua syarat, yaitu :

1. Jenjang pendidikan

Jenjang pendidikan adalah tahapan pendidikan yang ditetapkan berdasarkan tingkat perkembangan siswa, sebab perkembangan siswa harus disesuaikan dengan karakteristik dunia modern tanpa mengurangi karakteristik dunia klasik, yang demikian itu ada di lembaga pendidikan formal. Jenjang pendidikan formal terdiri dari :

\footnotetext{
${ }^{6}$ Heribertus Sutopo. 2002.Metodologi Penelitian Kualitatif. Surakarta: UNS Press, h. 91
} 
1) Pendidikan dasar, yaitu jenjang pendidikan awal 9 (sembilan) tahun pertama masa sekolah anak-anak yang melandasi jenjang pendidikan dasar.

2) Pendidikan menengah, yaitu jenjang pendidikan lanjutan pendidikan dasar.

3) Pendidikan tinggi, jenjang pendidikan setelah pendidikan menengah yang mencakup sarjana, magister, doktor dan spesialis yang diselenggarakan oleh perguruan tinggi.

2. Jurusan keilmuan

Lembaga pendidikan harus mempertimbangkan latar belakang pendidikan guru agar hasil pembelajaran maksimal dan menganalisis guru sebelum daftar ke lembaga pendidikan, jurusan pendidikan yang linear juga akan memberikan kualitas kepada lembaga pendidikan. C. V Good berpendapat dikutip olehAhmad Barizi mengatakan bahwa "guru pemula dengan latar belakang keguruan lebih mudah menyesuaikan diri dengan lingkungan sekolah, karena dia sudah dibekali seperangkat teori sebagai pendukung pengabdiannya, sedangkan guru bukan latar belakang pendidikan keguruan akan banyak menemukan banyak masalah dalam pembelajaran. ${ }^{7}$ Guru berbekal toeri tidaklah cukup, pengabdian dan pengalaman yang dilakukan hanya beberapa kali tidak merubahkarakteristik guru, karena guru tidak selalu dihadapkan dengan konsep, gagasan, cara, metode dalam pembelajaran, akan tetapi bagaimana guru berhubungan dengan komponen-komponen yang ada dalam lembaga pendidikan.

Jurusan yang dilatarbelakangi keguruan seiring berjalannya waktu akan menjadi guru profesional dengan bidang yang ditekuni, countinue menyempurnakan serta mengembangkan profesi guru, karena keprofesionalan guru bisa dilihat dari latar belakang pendidikan guru, seperti yang dikatakan oleh Sudarawan Danim “seorang guru dikatakan profesional atau tidak, dapat dilihat dari dua perspektif. Pertama latar belakang pendidikan dan ke-dua, penguasaan guru terhadap materi bahan ajar, mengelola pembelajaran, mengelola siswa, melakukan tugas bimbingan dan lain-lain. ${ }^{8}$ Keprofesionalan seringkali bisa disebut juga keahlian dalam suatu bidang tertentu, kinerja, kedisiplinan, tanggungjawab dalam menyelesaikan masalah siswa di kelas tanpa ada masalah lanjutan dan membuat damai salah satu pihak.

\footnotetext{
${ }^{7}$ Ahmad Barizi. 2009.Menjadi Guru Unggul.Yogyakarta: Ar-Ruzz Media, h. 142

${ }^{8}$ Sudarwan Danim. 2002.Inovasi Pendidikan dalam Upaya Peningkatan Profesionalisme Tenaga Kependidikan.Bandung: CV Pustaka Setia, h. 30.
} 
a. Proses Pendidikan Guru

Seseorang yang telah menjadi guru ia tidak langsung menjadi guru, melainkan membutuhkn prosesyang maksimal, mulai dari proses secara ekonomi, sosial, spriritual, mental dan pendidikan pra awal keguruan juga membutuhkan waktu yang lama dan kondisi yang maksimal. Keberhasilan sebuah sekolah dapat ditentukan oleh tujuan dari pendidikan yang mau dicapai dalam periode tertentu. ${ }^{9}$ AdapunPeraturan Pemerintah Nomor 19 Tahun 2005 yang diamandemen dengan Peraturan Pemerintah Republik Indonesia Nomor 32 Tahun 2013 TentangStandar Nasional Pendidikan ditegaskan bahwa Pendidik harus memiliki kualifikasi akademik dan kompetensi sebagai agen pembelajaran, sehat jasmani dan rohani, serta memiliki kemampuan untuk mewujudkan tujuan pendidkan nasional. Proses pendidikan guru melalui pendidikan formal, mulai dari pendidikan dasar hingga pendidikan tinggi, sebagai berikut :

1) Pendidikan TK/RA

Pendidikan paling dasar ini biasanya siswa masih brumur $4-6$ tahun pembelajaran sangat dasar, sistm pembelajaran ditunjukkan, diarahkan, dan dibimbing. TK atau RA merupakan bentuk pendidikan anak usia dini yang berada pada jalur pendidikan formal, sebagai mana dinyatakan dalam Undang-undang Sistem pendidikan Nasional Nomor 20 Tahun 2003 Pasal 28 "Pendidikan anak usia dini pada jalur pendidikan formal benrbentuk Taman Kanak-kanak (TK), Raudhatul Athfal (RA), atau bentuk lain yang sederajat". Istilah TK dan RA esensinya adalah sama, yang berbeda hanya dari segi bahasanya.

2) Pendidikan SD/MI

Elementary School atau Primary School dalam bahasa Inggrisadalah pendidikan paling dasar di Indonsia. Pendidikan dasar ini biasanya siswa berumur 7 - 12 tahun pembelajaran mulai memasuki ranah pengajaran, memberi pemahaman, dan menghafal materi-materi. Siswa dalam pendidikan ini umumnya ditempuh 6 tahun dengan 1 sampaai 6 kelas. Pendidikan dasar di Indonsia ada 2 corak, Sekolah Dasar Negeri/Sekolah Dasar Swasta dan Madrasah Ibtidaiyah Negeri/Madrasah Ibtidaiyah Swasta, masing-masingdikelola oleh Departemen yang berbeda dan masing-masing harus memiliki kualitas yang bagus dan kuantitas yang banyak.Kurikulum madrasah ibtidaiyah sama dengan kurikulum sekolah dasar, hanya saja pada MI terdapat porsi

\footnotetext{
${ }^{9}$ Muljawan Asep, Kepemimpinan Kepala Sekolah dalam Mengelola Sekolah Efektif, Jurnal Asy-syukriyah Vol. 19
} Nomor 1 Februari 2018, h. 149 
lebih banyak mengenai pendidikan agama Islam lbih diprinci ada Al-Quran dan Hadits, Aqidah dan Akhlaq, Fiqih, Sejarah Kebudayaan Islam dan Bahasa Arab.

3) Pendidikan SMP/ MTs

Sekolah Menengah Pertama(SMP) dan Madrasah Tsanawiyah (MTs) biasanaya ditempuh setelah pendidikan dasar selama 3 tahun kelas VII, VIII dan IX, pendidikan menengahumumnya siswa berumur 13 - 15 tahun pembelajaran mulai memasuki ranah pengajaran, memberi pemahaman, dan menganalisa materi-materi.Pendidikan menengah di Indonsia ada 2 corak, Sekolah Menengah Pertama Negeri/Sekolah Menengah Pertama Swasta dan Madrasah Tsanawiyah Negeri/Madrasah Madrasah Tsanawiyah Swasta, masing-masing dikelola oleh Departemen yang berbeda dan masing-masing harus memiliki kualitas yang bagus dan kuantitas yang banyak.Kurikulum Madrasah Tsanawiyah (MTs) sama dengan kurikulum Sekolah Menengah Pertama(SMP), hanya saja pada MI terdapat porsi lebih banyak mengenai pendidikan agama Islam lbih diprinci ada Al-Quran dan Hadits, Aqidah dan Akhlaq, Fiqih, Sejarah Kebudayaan Islam dan Bahasa Arab.

4) Pendidikan SMA/MA/SMK/MAK

Senior High School atau High School adalah nama lain dari SMA/MA/SMK/MAKmerupakan tingkatan akhir pada sekolah dasar dan sebagai pintu gerbang untuk melanjutkan ke perguruan tinggi ditempuh selama 3 tahun dengan 3 kelas yaitu kelas X, XI dan XII.Pendidikan menengah atas ini biasanya siswa berumur 16 - 18 tahun pembelajaran mulai memasuki ranah pengajaran, memberi pemahaman, menganalisa dan mampu menjelaskan materi-materi. Masing-masing dari lembaga yang setara tersebut tujuannya sama, hanya saja output dari lembaa tersebut berbeda SMK/MAK orientasinya langsung menjalani profesi setelah mengenyam pendidikan, sedangkan SMA/MA orientasinya lebih menambah pengetahuan, wawasan dan pengalaman di lingkungan atau diluar lingkungan pendidikan/perguruan tinggi formal.

5) Pendidikan Sarjana (S1)/Diploma IV (D IV)

Pendidikan/Perguruan tinggi ini biasanya siswa tidak dibatasi dengan umur, jenjang pendidikan ditempuh selama 4 tahun dengan 8 semester dengan SKS (Satuan Kredit Semester) sebanyak 144 hingga 166 SKS. Nama yang awalnya hanya siswa akan berubah menjadi mahasiswa, gelar yang disandang sebagai Sarjana berupa huruf diawali "S" setelah membuat dan menyelesaikan karya ilmiah yang dinamakan Skripsi . Pembelajaran sudah memasuki ranah fokus pembelajaran kejuruan, memberi 
pemahaman, mampu menganalisa, mampu menjelaskan, mampu bertanya jawab dan harus kritis.

6) Pendidikan Pascasarjana II (S2)

Pendidikan/Perguruan tinggi ini biasanya siswa/mahasiswa tidak dibatasi dengan umur, jenjang pendidikan ditempuh selama 2 sampai dengan 5 tahun, gelar yang disandang sebagai Magister berupa huruf diawali "M" setelah membuat dan menyelesaikan karya ilmiah yang dinamakan Tesis. Pembelajaran sudah memasuki ranah menganalisa, bertanggung jawab atas jawaban dan harus kritis secara teoritis dan ilmiah. Secara umum pendidikan ini melahirkan ilmuwan yangdapat berpengaruh kepada orangorang sekitar.

7) Pendidikan Pascasarjana III (S3)

Pendidikan/Perguruan tinggi ini biasanya siswa/mahasiswa tidak dibatasi dengan umur juga, jenjang pendidikan ditempuh selama 2 atau lebih, gelar yang disandang sebagai Doktor berupa dua huruf "Dr" di depan setelah membuat dan menyelesaikan karya ilmiah yang dinamakan Disertasi. Pembelajaran sudah memasuki ranah menganalisa, bertanggung jawab atas jawaban dan harus kritis secara teoritis ilmiah, melahirkan penemuan-penemuan baru, dan bijak dalam mengambil jawaban dan kesimpulan. Secara umum pendidikan ini melahirkan orang-orangintelektualorganik yang dapat berpengaruh kepada orang-orang sekitar.

\section{b. Teorisasi Guru Berlatar Belakang PAI dan non-PAI}

Istilah Guru PAI atau Pendidikan Agama Islam pada hakikatnya masing-masing beda arti, Guru adalah orang yang mampu memberikan pengetahuan, stimulus dan motivasi sertauntuk membangun potensi dan kompetensiindividu atau kelompok, senada dengan hal tersebut Sardiman AM mengatakan bahwa "guru merupakan salah satu komponen manusiawi dalam proses belajar mengajar, yang ikut berperan dalam proses pembentukan sumber daya manusia (SDM) dalam pembangunan bangsa ini. ${ }^{10}$ Pendidikan adalahproses pembelajaran yang mampu memberikan pengetahuan, stimulus, motivasi sekaligus tauladan kepada individu atau kelompok dalam suatu wadah (formal dan non-formal), sedangkan menurut menurut Heidjrachman dan Husnan pendidikan adalah suatu kegiatan untuk meningkatkan pengetahuan umum seseorang termasuk di dalam peningkatan penguasaan teori dan keterampilan, mutuskan dan mencari soluasi atas persoalan-persoalan yang

\footnotetext{
${ }^{10}$ SardimanA.M. 2001. Interaksi Dan Motivasi Belajar Mengajar.Jakarta: Raja Grafindo Persada, h. 123.
} 
menyangkut kegiatan dalam mencapai tujuannya, baik di dunia pendidikan atau kehidupan sehari-hari. ${ }^{11}$ Agama adalah wadah atau jalur yang dilalui seseorang untuk menjalani aturan yang perintah oleh Tuhannya, sehingga mencerminkan kehidupan sehari-hari dengan corak aturan yang dilaluinya, senada dengan pengertian tersebut Glock dan Stark mendefinisiakn agama sebagai sistem simbol, sistem keyakinan, sistem nilai, dan sistem perilaku yang terlembaga, yang semuanya terpusat pada persoalan-persoalan yang dihayati sebagai yang paling maknawi (Ultimate Mean Ipotetikin), ${ }^{12}$ Islam adalah ajaran yang dibawa oleh Nabi Muhammad mencakup ajaran syari'ah, ibadah, aqidah, akhlak yang diimplemantasikan dalam kehidupan sehari-sehari yang bersumber dari Sunnah Rasul (Al-Hadits) dan wahyu Tuhan (Al-Quran), sedangkan menurut M. Yatimin Islam adalah menyerah atau masuk Islam yaitu agama yang mengajarkan menyerahan diri kepada Allah SWT, tunduk dan patuh kepada hukum-hukumNya tanpa tawar menawar. ${ }^{13}$

Guru Pendidikan Agama Islam adalah seseorang yang memberikanpembelajarandari segi Ibadah, Syari'ah, Aqidah, Akhlak dengan mengkombinasikan edukasi dan etikakepada orang lain,memberikan tauladan dimanapun berada, sehingga bisa diimlementasikan dalam kehidupan sehari-hari.

Sedangkan guru non-PAI bersifat umum tetapi dalam hal ini akan lebih spesifik lagi, yaitu lebih membahas tentang guru yang berlatar belakang Ilmu Dakwah pada akhirnya dalam proses pembelajaran sering menggunakan metode ceramah yang membuat siswa cepat jenuh sifatnya monolog, Roestiyah NK menjelaskan "metode ceramah mempunyai keunggulan pula seperti yang kita lihat bahwa guru akan lebih mudah mengawasi ketertiban siswa dalam mendengarkan pelajaran, disebabkan mereka melakukan kegiatan yang sama. Bagi guru juga ringan, karena perhatiannya tidak terbagi-bagi atau terpecah-pecah. ${ }^{14}$

Guru yang belatar belakang non-PAI ini dalam komunikasi di dalam kelas menggunakan komunikasi satu arah artinya tidak ada timbal balik dari siswa dalam pembelajaran. Sebenarnya timbal balik kepada siswa suasana pembelajaran lebih menarik, dari sinilah nantinya guru mencari celah untuk melanjutkan materi pembelajaran, waktu akan lebih maksimal digunakan, menurut Piester "hambatan-hambatan yang mengganggu proses komunikasi antara lain: (1) Kurangnya penggunaan sumber komunikasi yang tepat,

\footnotetext{
${ }^{11}$ Heidjrachman dan Suad Husnan. 1997.Manajemen Personalia. Yogyakarta: BPFE, h. 77

${ }^{12}$ Zakiyah Daradjat. 2005. Ilmu Jiwa Agama.Jakarta: Bulan Bintang, h. 10

${ }^{13}$ Abdullah, M. Yatimin. 2005.Studi Islam Komtemporer.Jakarta : AMZAH, h. 7

${ }^{14}$ Roestiyah, NK. 2008.Strategi Belajar Mengajar (Jakarta: Rineka Cipta, h. 138.
} 
(2) Penampilan, (3) Sikap, (4)Kecakapan yang kurang tepat selama komunikasi, (5) Kuranggnya pengetahuan (komptensi), (6) Perbedaan persepsi, (7) Latar belakang pendidikan, (8) Budaya, (9) Sosial ekonomi, (10) Pesan yang tidak jelas dan disertai prasangka buruk, (11) dan lain-lain sebagainya"15

c. Tugas dan Syarat Guru

1. Tugas Guru

Persiapan guru dalam segala hal yang berkaitan dengan aktivitas belajar berdampak pada hasil belajar, persiapanguru membuat kreatifitas dalam pembelajaran membuat siswa lebih semangat dalam belajar, karena guru yang kretifitas akan memunculkan ideide baru yang tidak keluar dari standarisasi perturan yang telah ditetapkan, menurut Dedi Supriadi ada lima hal tugas guru diantaranya adalah, (1) Guru mempunyai komitmen pada siswa dan proses belajarnya. Ini berarti bahwa komitmen tertinggi guru adalah kepada kepentingan siswanya. (2) Guru menguasai secara mendalam bahan/mata pelajaran yang diajarkan serta cara mengajarkannya kepada siswa. Bagi guru, hal ini merupakan dua hal yang tidak dapat dipisahkan. (3) Guru bertanggung jawab memantau hasil belajar siswa melalui berbagai teknik evaluasi, mulai cara pengamatan dalam perilaku siswa sampai tes hasil belajar. (4) Guru mampu berpikir sistematis tentang apa yang dilakukannya, dan belajar dari pengalamannya. Artinya, harus selalu ada waktu untuk guru gunamengadakan refleksi dan koreksi terhadap apa yang telah dilakukannya. Untuk bisa belajar dari pengalaman, ia harus tahu mana yang benar dan salah, serta baik dan buruk dampaknya pada proses belajar siswa, dan (5) Guru seyogyanya merupakan bagian dari masyarakat belajar dalam lingkungan profesinya, misalnya PGRI dan organisasi profesi lainnya. ${ }^{16}$

Guru di kelas harus memperhatikan beberapa hal diantaranya adalah : (1) Guru harus merupakan seorang model dalam karakter. Dari awal hingga akhir pelajaran, tutur kata, sikap, dan perbuatan guru harus merupakan cerminan dari nilai- nilai karakter yang hendak ditanamkannya. (2) guru harus memberikan reward kepada siswa yang menunjukkan karakter yang dikehendaki dan pemberian punishment kepada mereka yang berperilaku dengan karakter yang tidak dikehendaki. Reward dan punishment yang dimaksud dapat berupa ungkapan verbal dan non verbal, kartu ucapan selamat (misalnya

\footnotetext{
${ }^{15}$ Herri Zan Piester. 2012.Pengantar Komunikasi \& Konseling Dalam Praktek Kebidanan.Jakarta: Prenada Media Group, h. 32

${ }^{16}$ Dedi Supriadi. 2005.Mengangkat Citra dan Martabat Guru. Yogyakarta: Adicita Karya Nusa, 1999, h. 98.
} 
classroom award), atau catatan peringatan, dan sebagainya. Untuk itu guru harus menjadi pengamat yang baik bagi setiap siswanya selama proses pembelajaran. (3) Guru harus menghindari mengolok-olok siswa yang datang terlambat atau menjawab pertanyaan dan/atau berpendapat kurang tepat/relevan. Karena kebiasaan tersebut harus dijauhi untuk menumbuh kembangkan sikap bertanggung jawab, empati, kritis, kreatif, inovatif, rasa percaya diri, dan sebagainya. (4) Guru memberi umpan balik dan/atau penilaian kepada siswa, guru harus mulai dari aspekaspek positif atau sisi-sisi yang telah kuat/baik pada pendapat, karya, dan/atau sikap siswa. (5) Guru menunjukkan kekurangankekurangannya dengan 'hati'. Dengan cara ini sikap-sikap saling menghargai dan menghormati, kritis, kreatif, percaya diri, santun, dan sebagainya. ${ }^{17}$

Tugas guru bukan hanya di lingkungan sekolah akan tetapi juga diluar lingkungan sekolah, memberikan tauladan kepada orang sekitar, orang menganggap bahwa yang dilakukan guru selalu baik mengikuti langsung tanpa menyaring, maka guru harus berhati-hati dalam bertingkah laku danguru dianggap bisa dalam segala bidang, walaupun bidang tersebut bukan kompetensinya, maka dari itu guru harus mempersiapkan dalam segala bidang, walaupun tidak secara maksimal. Kebanyakan guru tidak mengetahui esensi dan eksistensi keguruan, dikarenakan landasan penguasaan norrma-norma yang lemah dan sejumlah patologi sosial lainya. ${ }^{18}$

2. Syarat Guru

a) Syarat Eksternal Guru

Kualifikasi akademik guru dalam jabatan dapat diperoleh dengan pendidikan formal minimal sarjana (S1) di perguruan tinggi terakreditasi yang mengakui hasil pembelajarannya, termasuk pelatihan-pelatihan yang pernah diikuti dan sks mata kuliah selama berada diperguruan tinggidibuktikan dengan sertifikat/ijazah yang relevan sesuai dengan keahliannyaakan membuat calon guru lebih berkualitas, secara ekternal syarat menjadi guru diantaranya adalah dilihat dari latar belakang pendidikan dan memiliki ijazah/setifikat pendidik. Sedankang menurut Hamzah B. Uno ada lima syarat menjadi guruyang baik diantaranya, (1) Guru berijazah, (2) Guru harus sehat jasmani dan rohani, (3) Guru harus bertakwa kepada Tuhan yang Maha Esa dan

\footnotetext{
${ }^{17}$ Abdusshomad Alwazir, Pentingnya Penerapan Pendidikan Karakter dalam Pembelajaran, Jurnal AsySyukriyah Vol. 19 Nomor 1 Februari 2018, h. 47

${ }^{18}$ Najib Mohamad, Konsep dan Strategi Menciptakan Pendidikan Karakter di Madrasah, Jurnal Asy-Syukriyah Vol. 22 Nomor 1 Januari - Juni 2021, h. 66
} 
berkelakuan baik dan berkelakuan baik, (4) Guru harus bertanggung jawab, dan (5) Guru di Indonesia harus berjiwa sosial. ${ }^{19}$

Dari segi syarat eksternal Guru ini berkaitan dengan pendidikan formal lulusan sebagai sarjana (S1 atau setara Diploma IV) berpendidikan dibawah S1 (diploma I, II dan III). Lulusan SI atau D IV adalah minimal kualifikasi sebagai calon guru jabatan, sebagaimana tertulis dalam Undang-Undang tentang Guru dan Dosen Pasal I ayat IX, hal tersebut mencerminkan bahwa guru telah menguasai dibidang pendidikan hususnya menjadi seorang guru, syarat eksternal ini oleh Nana Subini disebut persyaratan administratif dan teknis, ${ }^{20}$ sedangkan menurut Djamarah disebut guru tersebut Ahli pada bidang yang diajarkan. ${ }^{21}$

b)Syarat Internal Guru

Guru yang memiliki mental spiritual yang tinggi akan membuat khawatir guru untuk tidak bertanggung jawab terhadap siswa, khawatir untuk menjelaskan hal yang tidak baik, dan khawatir bertingkah yang tidak baik, karena semua yang dijelaskan dan yang dilakukan guru oleh siswa dianggap baik. Guru yang memiliki kepribadian baik akan berdampak baik kepada siswa, sehingga mengubah siswa menjadi lebih baik, karena hal tersebut adalah salah satu syarat sebagai guru. Ada bebepa pendapat ahli syarat menjadi guru, diataranya adalah :

(1)Menurut Barnadib salah seorang ahli pendidikan di Indonesia, mengatakan bahwa syarat menjadi guru cukup berat tapi luhur dan mulia, diantara syaratnya adalah :22(a) Calon sungguh berbakat, (b) Pandai bahasa sopan, (c) Kepribadiannya harus baik dan kuat, (d) Harus disenangi dan disegani siswa, (e) Emosinya harus stabil, (f) Pandai menyesuaiakan diri, (g) Tidak boleh sensitif, (h) Harus tenang obyektif dan bijaksana, (i) Harus jujur dan adil, (j) Harus susila dalam tingkahlakunya, dan (k) Sifat sosialnya harus besar.

(2)Menurut Al Abrasi salah seorang ahli pendidikan Islam dari Mesir, mengemukakan beberapa syarat bagi seorang guru. Yaitu:23(a) Zuhud, tidak mengutamakan materi dan mengajar semata-mata karena Allah, (b) Bersih lahir dan batin, (c) Ikhlas dalam

\footnotetext{
${ }^{19}$ Hamzah B. Uno. 2010.Perencanaan Pembelajaran. Jakarta: Bumi Aksara, h. 29.

${ }^{20}$ Lihat, Nana Subini. 2012.awas, Jangan Jadi Guru Karbitan!: kesalahan-kesalahan Guru dalam Pendidikan dan Pembelajaran. Jogjakarta: Javalitera, h.9

${ }^{21}$ Syaiful Bahri Djamarah. 2000. Guru dan Anak Didik dalam Interaksi Edukatif. Jakarta: Rineka Cipta. h. 32.

${ }^{22}$ Sutari Iman Barnadib. 1982.Pengantar Ilmu Pendidikan Sistematis.Yogyakarta:Andi Offset, h. 73

${ }^{23}$ Muhammad AthiyahAl-Abrasi. 1974. Dasar-Dasar Pendidikan Islam. terj. H. Bustami A. Gani dan Johar Bakri.Jakarta: Bulan Bintang, h. 137-140
} 
pekerjaan, (d) Pemaaf, (e) Seorang bapak sebelum ia seorang guru, (f) Mengetahui tabi'at murid, dan (g) Menguasai mata pelajaran.

(3) Menurut Al-Nahlawi salah seorang ahli pendidikan Islam yang lain,menyatakan bahwa seorang guru itu harus memenuhi beberapa syarat, yaitu :24 (a) Tujuan, tingkah laku dan pola piker guru bersifat Rabbani, (b) Ikhlas, (c) Sabar, (d) Jujur, (e) Membekali diri dengan ilmu dan bisa mengkajinya, (f) Menguasai metode mengajar, (g) Mampu mengelola siswa, (h) Mengetahui kehidupan psikis siswa, (i) Tanggap terhadap berbagai kondisi dan perkembangan dunia yang mempengaruhi jiwa, keyakinan dan pola berpikir generasi muda, dan (j) Adil.

Syarat internal guru ini biasanya berkaitan dengan diri jasmani guru, baik dari jiwa spiritual, jiwa sosial dan jiwa individual. Jiwa spiritual guru dilihat dari kejujuran guru, keikhlasan guru, kesabaran guru, dan kezuhudan guru, sedangkan jiwa sosial guru dilihat dari pengelolaan kelas, penguasaan metode dalam pembelajaran, dan mampu berbuat adil terhadap siswa, yang terakhir jiwa individual dilihat dari pengetahuan guru tentang psikis siswa, membekali dengan ilmu pengetahuan, kesetabilan dalam mengolah emosi, dan lain sebagainya.

3. Syarat Konkrit Guru

Ruang linkup tugas gurubukan hanya mengajar dan mendidik dilingkungan sekolah akan tetapi juga memberikan pemahaman kepada masyarakat tentang formal ataupun non-formal, agarmemiliki cara pandang yang tepat dalam mengambil keputusan, masyarakat menganggap guru yang mampu menyelesaikan perrmasalahan tanpa memberatkan salah satu pihak, secara langsung atau tidak langsung, verbal atau non-verbal. Guru tidak boleh menghindar atau beralasan jika ada salah satu masyarakat bertanya tentang permasalahan, terkadang masyarakat bertanya dengan persoalan yang simpel tapi jawabannya harus logis dan mudah dicerna. Berikut adalah syarat-syarat menjadi guru menurut Piet A. Sahertian, ${ }^{25}(1)$ dalam menghadapi masalah selalu dapat mencari alternatif pemecahan masalah, (2) dapat menggeneralisasi sebagai alternatif dalam memecahkan masalah, (3) punya kepedulian kepada siswa dan teman sejawat, (4) selalu menyediakan waktu dan tenaga yang cukup untuk membantu siswa, (5) selalu

\footnotetext{
${ }^{24}$ Al AbdurrahmanNahlawi. 1989. Prinsip-prinsip dan Metode Pendidikan Islamdalam Keluarga. di Sekolah dan Masyarakat. terj. Herry Noer Ali.Diponegoro: Bandung, h. 239-246

${ }^{25}$ Piet A. Sahertian. 2000. Supervisi Pendidikan Dalam Rangka PengembanganSumber Daya Manusia. Jakarta: Rineka Cipta, h. 49
} 
mempedulikan tugas kelompok, (6) mempenyai kemampuan untuk mengembangkan dirinya terus-menerus.

Persepsi tentang kompetensi guru adalah pandangan atau penilaian terhadap kemampuan guru dalam menjalankan tugas mengajar dan mendidik. ${ }^{26}$ Begitu juga Peran dan tanggung jawab guru di masyarakat juga sentral, terkadang masyarakat tidak memandang tentang status disiplin ilmuguru dalam dunia pendidikan, masyarakat menganggap guru mengetahui segalanya, maka dari itu guru harus mempersiapkan dan memahami tentang kehidupan dan latar belakang masyarakat setempat, semuanya akan lebih mempermudah guru dalam menjawab permasalahan masyarakat.

d. Teorisasi Motivasi Belajar

Secara umum dalam dunia pendidikan motivasi belajar juga harus diperhatikan dalam proses belajar mngajar, proses belajar mengajar dikatakan maksimal apabila siswa giat dan semangat dalam proses pembelajaran, berbicara tentang motivasi dalam belajar erat kaitannya dengan dampak dari prosesbelajar, motivasi belajar bisa dilihat dari siswa yang semangat dalam mengikuti pembelajaran, pola fikir guru harus bisa membaca keadaan siswa, sifat kreatifitas dan inovatif guru harus dikembangkan dalam pembelajaran, dari segi metode pembelajaran atau komunikasi dalam menjelaskan sebuah materi. Mengenai motivasi belajar banyak tokoh pakar pendidikan menjelaskan tentang pengertian motivasi belajar, peran motivasi belajar, ciri dari siswa yang memiliki motivasi belajar, fungsi dari motivasi belajar, macam-macam motivasi belajar dan lain sebagainya. Semua mengalami perkembangan dan penyempurnaan seiring dengan perkembangan dunia yang semakin kompleks, pada teori pendidikan atau pembelajaran salah satunya adalah motivasi belajar ini, dibawah ini akan dijelaskan tentang beberapa ranah dalam teori motivasi belajar.

1. Peran Motivasi Belajar

Peran dari adanya motivasi pada siswa menurut Hamzah B. Uno adalah sebagai berikut :27

1) Peran motivasi belajar dalam menentukan penguatan belajar. Motivasi dalam proses pebelajaran membutuhkan kesiapan anak, guru dalam hal ini mampu membuat anak tetap semangat dalam proses pembelajaran, karena tidak mungkin

\footnotetext{
${ }^{26}$ Hilatun Nisa Ike, Pengaruh Perhatian Orang Tua dan Persepsi Atas Kompetensi Guru Terhadap Prestasi Belajar Sosiologi, Jurnal Asy-Syukriyah Vol. 21 Nomor 2 Oktober 2020, h. 146

${ }^{27}$ Hamzah B. Uno. 2011. Teori Motivasi dan Pengukurannya: Analisis di Bidang Pendidikan. Jakarta: Bumi Aksara, h. 27-29.
} 
dalam waktu beberapa menit tanpa ada perubahan situasi ataupun kondisi, anak selalu fokus mengikuti materi guru.

2) Peran motivasi dalam memperjelas tujuan belajar. Siswa yang semangat dalam belajar menyebabkan proses pembelajaran stabil, stimulus oleh guru penyebab siswa ingin selalu belajar pada akhirnya tujuan pembelajaran tercapai.

3) Motivasi menentukan ketekunan belajar. Salah satu penyebab siswa menjadi tekun dalam belajar, karena siswa tertarik dengan belajar ada variasi-variasi baru yang diberikan oleh guru baik, baik berupa ucapan ataupun perbuatan guru.

2. Fungsi Motivasi Belajar

Motivasi dalam proses pembelajaran dikelas dapat berfungsi sebagai:28

1) Mendorong timbulnya kelakuan/ suatu perbuatan.

2) Motivasi berfungsi sebagai pengarah, artinya mengarah pada perbuatan ke pencapaian tujuan yang diinginkan.

3) Motivasi berfungsi sebagai penggerak, artinya sebagai motor penggerak dalam kegiatan belajar.

Dari ketiga konsep yang ditawarkan oleh Oemar Hamalik diatas dapat disimpulkan dalam tiga kategori, karena motivasi yang ada pada siswa datang dari semua ranah intrinsik dan ekstrinsik dilihat dari faktornya, akan tetapi jika motivasi dilihat dari implementasi ada 3, yaitu, (1) dari luar, di dalam, dan kemudia ke luar, (2) di dalam, dan kemudian ke luar, dan (3) di dalam saja.

3. Ciri-ciri Siswa Termotivasi dalam Belajar

Ciri-ciri bagi siswa yang memiliki motivasi belajar adalah sebagai berikut :29

1) Tekun menghadapi tugas-tugas dan dapat bekerja terus-menerus sampai pekerjaannya selesai.

2) Ulet dan tidak mudah putus asa dalam menghadapi kesulitan.

3) Memungkinkan memiliki minat terhadap bermacam-macam masalah.

4) Lebih sering bekerja secara mandiri.

5) Cepat bosan dengan tugas-tugas rutin.

6) Jika sudah yakin dapat mempertahankan pendapatnya

7) Tidak akan melepaskan sesuatu yang telah diyakini.

${ }^{28}$ Oemar Hamalik. 2011. Proses Belajar Mengajar. Jakarta. PT Bumi Aksara, h. 108

${ }^{29}$ Sardiman A. M A. 2012. Interaksi Dan Motivasi Belajar Mengajar. Jakarta : Raja Grafindo Persada, h. 131 
8) Sering mencari dan memecahkan masalah soal-soal.

Sedangkan ciri-ciri siswa termotivasi dalam belajar yang digagas oleh Hamzah

B. Uno adalah sebagai berikut $:^{30}$

1) Adanya hasrat dan keinginan untuk berhasil.

2) Adanya dorongan dan kebutuhan dalam belajar.

3) Adanya harapan dan cita-cita di masa depan.

4) Adanya penghargaan dalam belajar.

5) Adanya kegiatan yang menarik dalam belajar.

6) Adanya lingkungan belajar yang kondusif, sehingga memungkinkan seorang siswa dapat belajar dengan baik.

Dalam hal ini ditawarkan pula tentang ciri-ciri anak yang termotivasi dalam belajar, sebagai berikut :

(1) Lebih fokus dalam mengikuti pembelajaran.

(2) Lebih memperhatikan guru

(3) Mengurangi bermain-main di dalam kelas bersama teman

(4) Mengurangi bermain-main sendiri di dalam kelas

(5) Menunggu variasi situasi selanjutnya dengan penuh rasa senang.

\section{Faktor yang Mempengaruhi Motivasi Belajar}

Pada hakikatnya konsep tentang faktor-faktor yang mempengaruhi motivasi ada telah banyak digagas oleh para tokoh, demikian ini dikarenakan perkembangan zaman yang sangat maju dan semakin kompleks dan harus terus dikembangkan dan disempurnakan. Dibawah ini ada beberapa faktor yang mempengaruhi motivasi belajar dan tidak jauh dengan pembahasan intrinsik dan ekstrinsik : ${ }^{31}$

1) Motivasi intrinsik, motivasi ini ada karena ada dorongan dari diri sendiri keinginan jangka panjang maupun keinginan jangka pendek,motivasi ini menjadi dua, yaitu :

\section{a. Faktor Fisik}

Faktor fisik meliputi nutrisi (gisi), kesehatan, dan fungsi-fungsifisik (terutama panca indera).

b. Faktor Psikologis

\footnotetext{
${ }^{30}$ Hamzah B. Uno. 2011. Teori Motivasi dan Pengukurannya: Analisis di Bidang Pendidikan. Jakarta: Bumi Aksara, h. 23.

${ }^{31}$ Sardiman A. M. 2007. Interaksi dan Motivasi Belajar Mengajar. Jakarta : Raja Grafindo Persada, h.89-91
} 
Faktor psikologis berhubungan dengan aspek-aspek yang mendorong atau menghambat aktivitas belajar pada siswa.

2) Motivasi ekstrinsik, motivasi ini biasanya ada dorongan dari luar siswa, bisa dari teks atau non-teks dan materi ataupun immateri, kebanyakan siswa dalam ranah ekstrinsik yang mendapatkan dorongan juga ada dua kategori, yaitu :

\section{a. Faktor Non-Sosial}

Faktor non-sosial meliputi keadaan udara (cuaca panas atau dingin), waktu (pagi, siang, malam), tempat (sepi, bising, atau kualitas sekolah tempat belajar), sarana dan prasarana atau fasilitas belajar.

b. Faktor Sosial

Faktor sosial adalah faktor manusia (guru, konselor, dan orang tua), baik yang hadir secara langsung maupun tidak langsung (foto atau suara). Proses belajar akan berlangsung dengan baik, apabila guru mengajar dengan cara menyenangkan, seprti bersikap ramah, memberi perhatian pada semua siswa, serta selalu membantu siswa yang mengalami kesulitan belajar. Pada saat di rumah siswa tetap mendapat perhatian orang tua, baik material dengan menyediakan sarana dan prasarana belajar guna membantu dan mempermudah siswa belajar di rumah. ${ }^{32}$

Pendidikan yang berada di bawah naungan Yayasan Pesantren Islam beralamat Jl. Kompi Udin RT.06/RW. 05, Pegangsaan II Kelapa Gading Jakarta Utara ini memiliki Guru yang berlatarbelakang Pendidikan Strata Satu (S-1) memiliki kompetensi-kompetensi yang berbeda-beda, memiliki tiga kelas dari TPQ sampai dengan Madrasah Diniyah dan masing-masing kelas anak dibatasi maksimal 30 anak, sedangkan dalam penelitian ini fokus kepada anak yang tingkatan Ulya (SMA/SMK/MA).Dari 30 siswa dibawah ini adalah kesimpulan kemudian direduksi dua sampai tiga kali jawaban siswa terhadap dua Guru yang berlatarbelakang berbeda tersebut :

Kemudian diambil kesimpulan oleh Peneliti dari wawancara, observasi dan dianalisis secara berkala kemudian direduksi dari keadaan di dalam kelas sehingga memunculkan :

\footnotetext{
${ }^{32}$ Syamsu Yusuf. 2009. Program Bimbingan dan Konseling di Sekolah. Bandung: Rizqi Press, h. 23.
} 


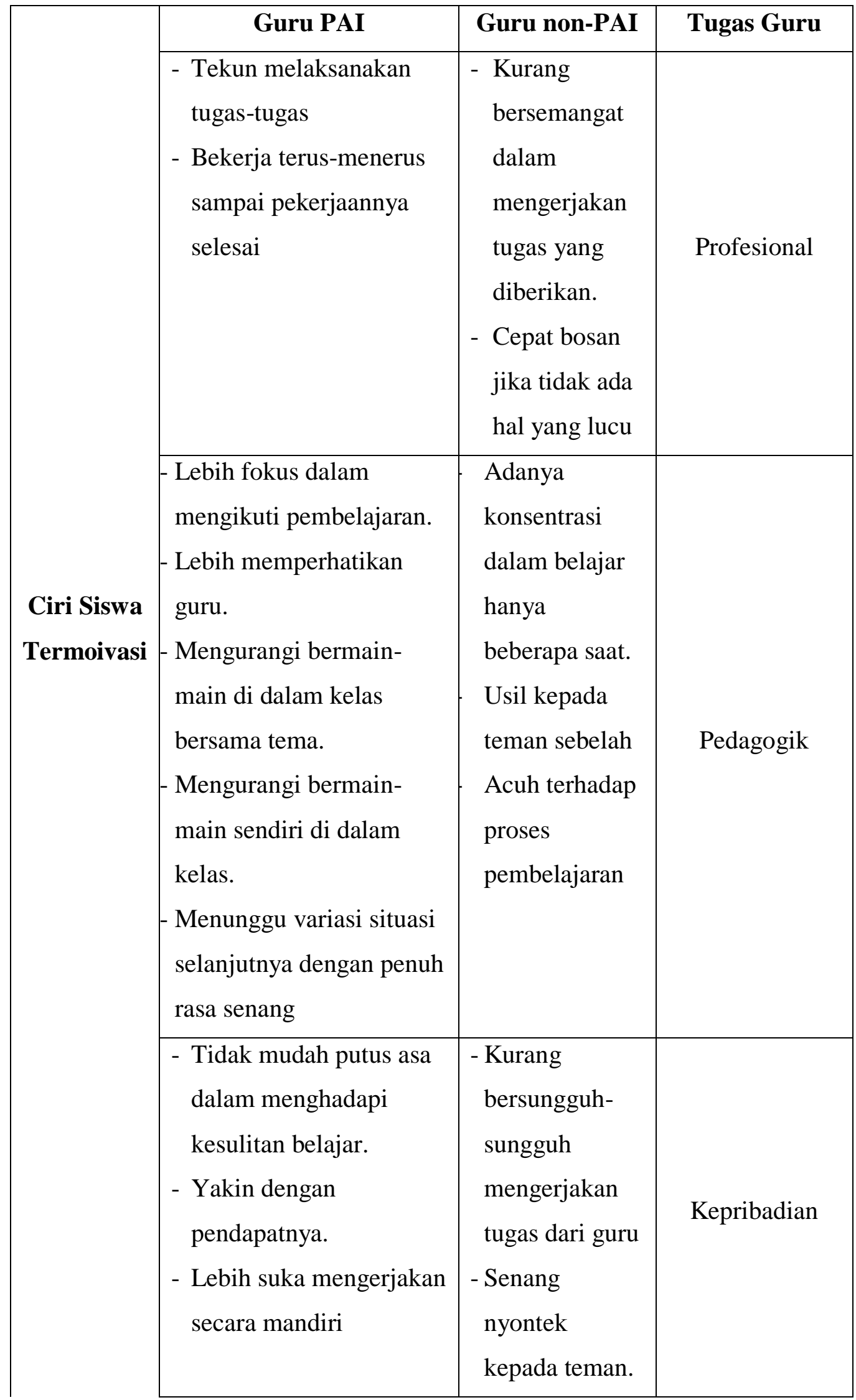




\begin{tabular}{|c|c|c|}
\hline & $\begin{array}{l}\text { - Tidak percaya } \\
\text { dengan } \\
\text { jawaban } \\
\text { sendiri }\end{array}$ & \\
\hline $\begin{array}{l}\text { - Mengkritik pendapat } \\
\text { teman tanpa menyakiti. }\end{array}$ & $\begin{array}{l}\text { - Berat hati } \\
\text { disaat ada } \\
\text { teman yang } \\
\text { bertanya. } \\
\text { - Tidak ada } \\
\text { keseriusan } \\
\text { dalam } \\
\text { bertanya. }\end{array}$ & Sosial \\
\hline
\end{tabular}

\section{KESIMPULAN}

Latar belakang pendidikan yang berbeda mempengaruhi motivasi belajar yang tidak maksimal, latar belakangpendidikan dapat dilihat dari pendidikan formal atau kualisi akademik Sarjana Strata Satu (S1) pada perguruan tinggi yang terakreditasi, banyak jurusan-jurusan yang disediakan oleh beberapa perguruan tinggi negeri atau swasta. Guru yang berlatarbelakang nonPAI hanya berorientasi pada goal oriented atautransfer of knowledge hanya fokus materi yang disampaikan, sehingga motivasi belajar dari segi gerak kreatif (creativity) kaku, siswaselalu bertanya pekerjaan apa yang hendak dilakukan selanjutnya, guru harus sistematis dan detail dalam pelaksanaan pra-pembelajaran, proses pembelajaran dan pasca-pembelajaran. Sedangkan guru yang berlatar belakang PAI orientasinya pada value oriented atauvalueof knowledge akan lebih menyusun dengan sistematis pra-pembelajaran, proses pembelajaran dan pasca-pembelajaran secara teknis dan non-teknis, sehingga kemampuan siswa benar-benar terasah dan mempunyai terobosan-terobosan baru di dalam kelas dari segi materi atau aktivitas siswa, ini berindikasi pada peran atau tugas pedagogik Guru PAI dan Guru non-PAI .

Diantara aspek-aspek hasil belajar ada 3 yaitu, (1) Ranah kognitif (cognitive domain)berkaitan denganpengetahuan (knowlegde), pemahaman (comprehension), penerapan (application)analisis (analysis), sintesis (synthesis), dan evaluasi (evaluation), (2) Ranah afektif (affective domain) berkaitan dengan penerimaan (receiving),partisipasi(responding),penilaian atau penentuan sikap (valuing), organisasi (organization), dan pembentukan pola hidup (characterization by avalue), (3) Ranah psikomotor (psychomotoric domain)berkaitan dengan persepsi (perception), kesiapan (set), gerakan terbimbing (guided response), gerakan yang 
terbiasa (mechanical response), gerakan yang kompleks (complex response), penyesuaian pola gerakan (adjusment), dan kreativitas (creativity). 


\section{DAFTAR PUSTAKA}

Abdullah, M. Yatimin. 2006. Studi Islam Komtemporer. Jakarta : AMZAH.

Ali Khan Shafique. 2005. Filsafat Pendidikan Al-Ghazali. Bandung : Pustaka setia.

A.M Sardiman. 2001. Interaksi Dan Motivasi Belajar Mengajar. Jakarta: Raja Grafindo Persada.

Arikunto Suharsimi. 1996. Dasar-dasar Evaluasi Pendidikan. Jakarta: Bumi Aksara.

Athiyah Al-Abrasi Muhammad. 1974. Dasar-Dasar Pendidikan Islam. terj. H. Bustami A. Gani dan Johar Bakri. Jakarta: Bulan Bintang.

Sahertian Piet. 2000. Supervisi Pendidikan Dalam Rangka Pengembangan Sumber Daya Manusia. Jakarta: Rineka Cipta.

Bahri Djamarah Syaiful. 2000. Guru dan Anak Didik dalam Interaksi Edukatif . Jakarta: Rineka Cipta.

Bahri Djamarah Syaiful. 2002. Psikologi Belajar. Jakarta: Reneka Cipta.

Barizi Ahmad. 2009. Menjadi Guru Unggul. Yogyakarta: Ar-Ruzz Media.

B. Uno Hamzah. 2010. Perencanaan Pembelajaran. Jakarta: Bumi Aksara.

Creswell, J. W. 2013. Penelitian Kulalitatif \& Desain Riset. Yogjakarta: PT Pustaka Pelajar.

Daradjat Zakiyah. 2005. Ilmu Jiwa Agama. Jakarta: Bulan Bintang.

Darajat Zakiah. 1995. Metodik Khusus Pengajaran Agama Islam. Jakarta: Bumi Aksara.

Danim Sudarwan. 2002. Inovasi Pendidikan dalam Upaya Peningkatan Profesionalisme Tenaga Kependidikan. Bandung: CV Pustaka Setia.

Dimyati dan Mudjiono. 2009. Belajar dan Pembelajaran. Jakarta: Rineka Cipta.

E. Mulyasa. 2006. Menjadi Guru Profesional. Bandung: Remaja Rosdakarya.

Hamalik Oemar. 2004. Proses Belajar Mengajar. Jakarta : Bumi Aksara.

Heidjrachman dan Suad Husnan. 1997. Manajemen Personalia. Yogyakarta: BPFE.

Iman BarnadibSutari. 1982.Pengantar Ilmu Pendidikan Sistematis. Yogyakarta:Andi Offset.

Jihat Asep. 2012. Evaluasi Pembelajaran. Yogyakarta: Multi Pressindo.

John W. Santrock, Psikologi Pendidikan, terj. Tri Wibowo,

Kurniawan Deni. 2011. Pembelajaran Terpadu. Jakarta: Pustaka Cendekia Utama.

Nahlawi Al Abdurrahman. 1989. Prinsip-prinsip dan Metode Pendidikan Islam dalam Keluarga. di Sekolah dan Masyarakat. terj. Herry Noer Ali. Diponegoro: Bandung.

Roestiyah, NK. 2008. Strategi Belajar Mengajar. Jakarta: Rineka Cipta.

Rosyada Dede. 2004. Paradigma Pendidikan Demokratis. Jakarta : Kencana.

Sherwood Lauralee. 2012. Fisiologi Manusia dari Sel ke Sistem. Jakarta: EGC. 
Subini Nana. 2012. awas, Jangan Jadi Guru Karbitan!: kesalahan-kesalahan Guru dalam Pendidikan dan Pembelajaran. Jogjakarta: Javalitera.

Supriadi Dedi. 1999. Mengangkat Citra dan Martabat Guru. Yogyakarta : Adicita Karya Nusa.

Sudjana Nana. 2000. Cara Belajar Siswa Aktif. Bandung: Sinar Baru Algensindo.

Sudjana Nana. 1989. Penilaian Hasil Proses Belajar Mengajar. Bandung: PT. Remaja Rosdakarya.

Sutopo Heribertus. 2002. Metodologi Penelitian Kualitatif. Surakarta: UNS Press.

Syah Muhibin. 2012. Psikologi Belajar. Jakarta: PT. Rajagrafindo.

W. S. Winkel. 1987. Psikologi Pengajaran. Jakarta: Gramedia.

Yamin Martinis. 2007. Profesionalisasi Guru dan Implementasi KTSP. Jakarta: Gaung Persada Press.

Yaumi Muhammad. 2013. Prisip-Prinsip Desain Pembelajaran. Jakarta: Kencana.

Zan Piester Herri. 2012. Pengantar Komunikasi \& Konseling Dalam Praktek Kebidanan. Jakarta: Prenada Media Group.

Almaydza Pratama Abnisa, Konsep Motivasi Pembelajaran, Jurnal Ay-Syukriyah Vol. 21 Nomor 2 Oktober 2020

Alwazir Abdusshomad, Pentingnya Penerapan Pendidikan Karakter dalam Pembelajaran, Jurnal Asy-Syukriyah Vol. 19 Nomor 1 Februari 2018

Aris Setyawan, Efektifitas Metode Dicovery Learning dalam Meningkatkan Hasil Belajar Bahasa Inggris Siswa, Jurnal Asy-Syukriyah, Vol. 20 Nomor 2 Oktober 2019

Asep Muljawan, Kepemimpinan Kepala Sekolah dalam Mengelola Sekolah Efektif, Jurnal Asysyukriyah Vol. 19 Nomor 1 Februari 2018

Asep Muljawan, Model dan Strategi Manajemen Lembaga Pendidikan Islam, Jurnal AsySyukriyah Vol. 20 Nomor 2 Oktober 2019

Destiani Rahmawati,Preparation ff Paper For ${ }^{2 n d}$ Icel 2014 The Effectiveness Of Using Cooperative Learning Type Number Heads Together (Nht) Improving Reading Comprehansion Of The Students At Smp N 20 Tangerang, Jurnal As-Syukriyah Vol. 12 Edisi April 2014

Mohamad Najib, Konsep dan Strategi Menciptakan Pendidikan Karakter di Madrasah, Jurnal Asy-Syukriyah Vol. 22 Nomor 1 Januari - Juni 2021

Muh Muaidi, Motivasi Belajar Bahasa Inggris Praja Pada Institut Pemerintahan dalam Negeri (IPDN) Kampus Nusa Tenggara Barat, Jurnal Ay-Syukriyah Vol. 20 Nomor 1 Februari 2019

Ike Hilatun Nisa, Pengaruh Perhatian Orang Tua dan Persepsi Atas Kompetensi Guru Terhadap Prestasi Belajar Sosiologi, Jurnal Asy-Syukriyah Vol. 21 Nomor 2 Oktober 2020 
Rahmat Solihin, Pengembangan Media Pembelajaran Interaktif Tahfidz Al-Quran di Sekolah Dasar, Jurnal Ay-Syukriyah Vol. 21 Nomor 2 Oktober 2020 